\title{
Morphometric variations of laelapine mite (Acari: Mesostigmata) populations infesting small mammals (Mammalia) in Brazil
}

\author{
Martins-Hatano, F. ${ }^{a *}$, Gettinger, D. ${ }^{b}$, Manhães, ML. ${ }^{c}$ and Bergallo, $H G .^{d}$ \\ ${ }^{a}$ Universidade Federal Rural da Amazônia - UFRA, Av. Presidente Tancredo Neves, 2501, Montese, \\ CEP 66077-901, Belém, PA, Brazil \\ ${ }^{b}$ Harold W. Manter Laboratory of Parasitology, University of Nebraska-Lincoln - UNL, Lincoln, NE, USA \\ 'Laboratório de Ixodides, Fundação Oswaldo Cruz - FIOCRUZ, Rio de Janeiro, RJ, Brazil \\ ${ }^{d}$ Departamento de Ecologia, Instituto de Biologia, Universidade do Estado do Rio de Janeiro - UERJ, \\ Rio de Janeiro, RJ, Brazil \\ *e-mail: martinshatano@gmail.com
}

Received June 13, 2011 - Accepted October 4, 2011 - Distributed August 31, 2012

(With 4 figures)

\begin{abstract}
The goal of this study was to evaluate the morphometric variation of laelapine populations (Acari, Mesostigmata) associated with neotropical oryzomyine rodents at different geographic localities in Brazil. Three nominal mite species were selected for study, all infesting the pelage of small mammals at different localities in Rio de Janeiro, Espírito Santo, Bahia, and the Federal District, Brazil. To analyse morphometric characteristics, thirty-seven morphological characters distributed across the whole body of each specimen were measured. We use the Analysis of Principal Components, extracting the three first axes and projecting each mite in these axes. Major species level changes in the taxonomy of the host mammals allows an independent examination of morphometric variation of mites infesting a set of distinctly different host species at different geographic localities. Gigantolaelaps vitzthumi and Laelaps differens are associated with oryzomyine rodents of the genus Cerradomys, and consistently showed a tendency to cluster by host phylogeny. Laelaps manguinhosi associated with Nectomys rattus in central Brazil is morphometrically distinct from mites infesting N. squamipes in the coastal restingas of Rio de Janeiro and Espírito Santo. The results obtained here indicate that laelapine mite populations can vary among geographic areas and among phylogenetically related host species. Clearly, the study of these mites at the population level can be an important tool for clarifying the taxonomy of both mites and hosts.
\end{abstract}

Keywords: Brazil, ectoparasites, Gigantolaelaps, Laelaps, rodents.

\section{Variações morfométricas de populações de ácaros lelapíneos (Acari: Mesostigmata) que infestam pequenos mamíferos}

\begin{abstract}
Resumo
O objetivo deste estudo foi avaliar a variação morfométrica de populações de lelapíneos (Acari, Mesostigmata) associados com pequenos roedores oryzomíneos neotropicais, em diferentes localidades geográficas do Brasil. Três espécies nominais de ácaros foram selecionadas para este estudo, sendo aqueles que infestam a pelagem de pequenos mamíferos em diferentes localidades nos Estados de Rio de Janeiro, Espírito Santo e Bahia, e no Distrito Federal. Para analisar as características morfométricas, 37 caracteres morfológicos, distribuídos por todo o corpo de cada espécime, foram medidos. Nós usamos a Análise de Componentes Principais, extraindo os três primeiros eixos e projetando as medidas de cada ácaro nesses eixos. Mudanças importantes na taxonomia dos mamíferos hospedeiros permitem um exame independente da variação morfométrica de ácaros que infestam um grupo de espécies de hospedeiros distinto, em diferentes localidades geográficas. Gigantolaelaps vitzthumi e Laelapsdifferens estão associados com roedores orizomíneos de gênero Cerradomys e, consistentemente, mostraram uma tendência a se agrupar pela filogenia do hospedeiro. Laelaps manguinhosi associado com Nectomys rattus no Brasil Central é morfometricamente distinto das populações de ácaros que infestam $N$. squamipes nas restingas costeiras de Rio de Janeiro e Espírito Santo. Os resultados obtidos neste estudo indicam que populações de ácaros laelapíneos podem variar entre áreas geográficas e, especialmente, entre espécies hospedeiras relacionadas filogeneticamente. Claramente, o estudo desses ácaros em nível populacional pode ser uma importante ferramenta para esclarecer a taxonomia tanto dos ácaros quanto de seus hospedeiros.
\end{abstract}

Palavras-chave: Brasil, ectoparasitos, Gigantolaelaps, Laelaps, roedores. 


\section{Introduction}

The evolutionary expression of individual attributes is variable through time in biological systems. Species change continually, modifying the morphology and physiology of the individuals of each population, in response to characteristics of both the physical environment and the interactions with other organisms (Ricklefs, 1993). Among ectoparasitic arthropods, both short life cycles and reduced time between generations allow strong alterations in the populations and fast differentiation among them, especially when subjected to different selective pressures (Price, 1976). One of the consequences of the isolation of subpopulations and their independent evolutionary change is speciation. The increasing specialisation of diverging host species may increase the level of specialisation of parasites infesting these host groups (Price, 1976; Ricklefs, 1993; Begon et al., 1996). Mathematical analyses have been widely used in entomology and acarology to detect morphometric variations among populations and consequently, have clarified the dynamics of their speciation (Albrecht, 1979; Foottit and Mackauer 1990; Querino and Zucchi 2002). Multivariate statistical techniques are frequently used to order large morphometric datasets. In this way, the biological parameters producing morphological variation among individuals or groups can be resolved (Albrecht, 1979).

In the neotropics, mites of the subfamily Laelapinae (Acari, Laelapidae) are the most abundant arthropod group found in the fur of small terrestrial mammals. Previous studies focusing on ectoparasites of small mammals or in particular on laelapine mites, have described community composition and host associations in different areas and hosts of Brazil (Botelho and Williams, 1980; Linardi et al., 1984, 1985, 1991; Gettinger, 1987; Barros et al., 1993; Martins-Hatano et al., 2000, 2011; Bittencourt and Rocha, 2002; Bossi et al., 2002), or have described new species (Gettinger, 1992b, 1997; Gettinger and Bergallo, 2003). Morphologic variations among mite populations of different areas have rarely been studied (Gettinger, 1992a; Gettinger and Owen, 2000; Botelho et al., 2002).

Species of the genus Gigantolaelaps Fonseca, 1939 are nidicolus mites of wild rodents from Central and South America, characterised by their great size (dorsal shield length more than $1400 \mu \mathrm{m}$ ) (Furman, 1972). This genus shows a predilection for oryzomyine rodents (Cricetidae, Sigmodontinae), and tends to be specific to these hosts (Guitton et al., 1986; Gettinger, 1987; Linardi et al., 1991; Barros et al., 1993; Martins-Hatano et al., 2002; Bittencourt and Rocha 2003).

Gettinger (1992a); Gettinger and Owen (2000) have demonstrated that morphometric variations can occur among laelapine mite populations associated with different host species. This research implies that the morphologic characteristics of these mites can be influenced by the species identity of the host and that morphometric data can provide an important tool to clarify the taxonomy of both mites and hosts.
When this study was carried out, we had strong collections of Gigantolaelaps vitzthumi Fonseca, 1939, Laelaps differens Fonseca, 1936, and L. manguinhosi Fonseca, 1936, from coastal localities of restinga in Rio de Janeiro, Espírito Santo, and Bahia states, from the senior author's (FMH) doctoral project, and then also, from the cerrados and gallery forests of central Brazil, from another doctoral project (DG), near Brasília. Two host "species" that we had in common were "Oryzomys" subflavus and Nectomys squamipes. The goal of the original study was to evaluate the morphometric variation of laelapine populations associated with a single host species in different geographic areas. At that time, our G. vitzthumi and L. differens collections from all these localities were considered hostspecific associates of a single widely distributed host species, Oryzomys subflavus; and Laelaps manguinhosi, a specific associate of Nectomys squamipes, another wide-ranging host. We were interested more in geographic variation in mite populations than genetic variation of the hosts. However, following major revisionary changes in the taxonomy of the rodent tribe Oryzomyini (Weksler et al., 2006), and the genera Cerradomys (Percequillo et al., 2008; Tavares et al., 2011) and Nectomys (AndradesMiranda et al., 2001), we can apply this analysis to an equally interesting set of questions:

1) Are there recognisable morphometric differences among populations of Gigantolaelps vitzthumi, or of Laelaps differens collected from different three distinct host species of the genus Cerradomys, at three different geographic localities?

2) Are there quantitative morphometric differences among populations of Laelaps manguinhosi collected from Nectomys squamipes (Brants, 1827) at two localities in the state of Rio de Janeiro, and those collected from $N$. rattus (Pelzeln, 1883) in the Federal District of central Brazil?

\section{Material and Methods}

The mites and hosts were collected in four different geographic areas and at different time periods. The areas were: 1) the Restinga de Jurubatiba National Park, in Rio de Janeiro State (RJ), 2) Restinga of Praia de Neves, in Espírito Santo State (ES), 3) Distrito Federal (DF) and 4) the Chapada Diamantina, in the state of Bahia (BA).

"Restingas" sensu lato are sand dune habitats characteristic of the Atlantic forest (Oliveira-Filho and Fontes, 2000), that occur in the lowlands along the Brazilian coast. Restingas are formed "by sandy substrates resulting from the marine deposits of the Quaternary period and frequently include freshwater or brackish lagoons (Suguio and Tessler, 1984; Turcq et al.,1986). These habitats are relatively open and include herbaceous formations in the beach border, shrub formations, forest formations in depressions and on sand dunes, and vegetation on lagoon margins (Araújo, 1992). The Restinga de Jurubatiba National Park is located in north coast of Rio de Janeiro 
State $\left(22^{\circ}\right.$ and $22^{\circ} 23^{\prime} \mathrm{S}$ and $\left.41^{\circ} 45^{\prime} \mathrm{W}\right)$, covering a total area of $144,5 \mathrm{~km}^{2}$. The collections were made three times per year and included five different vegetable formations of the park from February 2001 to November 2002. Mammals were collected in seven transects located in different plant formations. In each transects we placed 20 live traps, distant $40 \mathrm{~m}$ apart from each other. Traps were opened during six nights and after the third night the traps were moved 20 m (Bergallo et al., 2004; Martins-Hatano et al., 2001). The total trapping effort in each year was 6360 trap-nights (Bergallo et al., 2004). At Praia de Neves ( $21^{\circ} 15^{\prime} 296^{\prime \prime} \mathrm{S}$ and $40^{\circ} 57^{\prime}$ '991") small mammals were captured and ectoparasites collected for three consecutive days in November 1999. Mammals were collected in live traps during two nights in transects located in different plant formations. The total trapping effort was 200 trapnights (Rocha et al., 2005)

Mites from the Cerrado Province were collected in Distrito Federal and in Chapada Diamantina. In Distrito Federal (DF) the collections were accomplished in July 1983 to November 1984 in two adjacent reserves, $12 \mathrm{~km}$ from Brasilia (15 ${ }^{\circ} 57^{\prime} \mathrm{S}$ and $47^{\circ} 54^{\prime} \mathrm{W}$ ) (Gettinger, 1992a). Mites from Chapada Diamantina in northeastern Brazil were collected in a municipal district of Itaetê, BA (13 ${ }^{\circ} 09^{\prime} 46^{\prime}$ S and $42^{\circ} 10^{\prime} 58^{\prime \prime} \mathrm{W}$ ), during May 2004. Cerrado is savannalike habitat that covers $12 \%$ of Brazilian territory. Mite voucher specimens from Bahia: Chapada Diamantina; Espírito Santo: Praia das Neves; and Rio de Janeiro: Restinga de Jurubatiba were deposited in the Coleção de Artrópodes Vetores Ápteros de Importância em Saúde das Comunidades (CAVAISC), FIOCRUZ, Rio de Janeiro, Brazil; voucher mite specimens from the DF collection were deposited in the Harold W. Manter Laboratory of Parasitology, University of Nebraska-Lincoln, U.S.A. Host voucher material is deposited in Oklahoma Museum of Natural History (OMNH) of the University of Oklahoma, Norman, Oklahoma, USA; in the Department of Animal Biology of the University of Brasília, Brazil; the Instituto Brasileiro de Geografia e Estatística (IBGE), Brasília, Brazil and in the Museu Nacional do Rio de Janeiro, Rio de Janeiro. In all areas the mammals were brushed, and ectoparasites were preserved in $70 \%$ ethyl alcohol (for more details of arthropods collection and preservation technique see Martins-Hatano et al., 2002, 2011).

The mites were mounted on slides in Hoyer's medium and measured with an ocular-micrometer of the compound light microscope. Thirty-seven morphological characters distributed across the whole body of each mite individual were measured, as described by Gettinger (1992a): 1) Dorsal shield length (DSL); 2) dorsal shield width at midlevel (DSW); 3) distance between j5 setae (j5-j5); 4) distance between z5 setae (z5-z5); 5) length of j5 (j5L); 6) length of z5 (z5L); 7) distance between J5 setae (J5-J5); 8) distance between Z5 setae (Z5-Z5); 9) length of J5 (J5L); 10) length of Z5 (Z5L); 11) distance between subcapitular setae (CAPCAP); 12) length of subcapitular setae (CAPL); 13) length of inner hypostomal setae (INNL); 14) distance between subcapitular and inner hypostomal setae (CAP-INN);
15) length of sternal shield (SSL); 16) width of sternal shield at level at second sternal setae (SSW); 17) distance between first sternal setae (S1-S1); 18) distance between third sternal setae (S3-S3); 19) length of anterior sternal setae (S1L); 20) length of posterior sternal setae (S3L); 21) length of epigynial shield (ESL); 22) distance between epigynial setae (E5-E5); 23) greatest width of epigynial shield (ESW); 24) length of poststernal setae (S4L); 25) length of epigynial setae (E5L); 26) length of paranal setae (PARAL); 27) length of postanal seta (POSTL); 28) distance from postanal seta to anterior midline of anal shield (POST-EDGE); 29) distance between paranal setae (PARA-PARA); 30) greatest width of anal shield (ASW); 31) length of proximal seta, coxa I, (PROXCOX); 32) length of distal seta, coxa I (DISTCOX); 33) length of posterior seta, coxa II (POSTCOX2); 34) length of posterior seta, coxa III (POSTCOX3); 35) length of posterior seta, coxa IV (POSTCOX4); 36) length of anterior dorsal seta, femur I (DFEM1L); 37) length of posterior dorsal seta, genu I (DGEN1L). Examples of measurements can be seen in Figure 1. In some analyses, measures were excluded when the structure being measured was not visible or had been damaged during the mounting process.

\subsection{Statistical treatment}

Ordination techniques consist of projecting objects graphically along axes representing a relational ordinate, or forming a dispersion diagram with two or more axes (Legendre and Legendre, 1988). The graphical axes are chosen to represent the greatest fraction of variability of given multidimensional data, in a space with reduced dimensionality related to the set of original data (Legendre and Legendre, 1988).

To reduce dimensionality of the morphometric data we use the Analysis of the Principal Components, extracting the three first axes and projecting each mite on these axes (Legendre and Legendre, 1988). To accomplish this analysis, we used the Systat 11.0 program.

\section{Results}

\subsection{Studied species}

\subsubsection{Gigantolaelaps vitzthumi Fonseca, 1939}

The occurrence of Gigantolaelaps vitzthumi in association with the species of the former Cerradomys subflavus (Wagner 1842) group has been reported from several geographic localities in Brazil (Lizaso, 1968; Gettinger, 1987). Since Weksler et al. (2006) formally described the genus Cerradomys, it has been revised considerably. In this study, mite populations were collected from three distinct species of hosts, C. scotti (Langguth and Bonvicino, 2002), near Brasília, DF, C. vivoi Percequillo, Hingst-Zaher and Bonvicino, 2008 from the Chapada Diamantina, BA, and C. goytaca Tavares, Pessoa and Gonçalves, 2011, from Praia das Neves, ES, and Restinga de Jurubatiba, RJ. Twenty mites collected from the fur of the mammals were randomly chosen and measured ( 4 from Restinga de 
Jurubatiba, 7 from Distrito Federal and 9 from Chapada Diamantina) (Table 1).

For Gigantolaelaps vitzthumi, the mites from C. vivoi (BA) formed a distinct cluster, well separate from specimens from $C$. goytaca (RJ) and C. scotti (DF) (Figure 2). The three first eigenvalues were, respectively, 12.00, 6.98 and 4.61 , being the total variation explained of $63.6 \%(32.4 \%$, $18.9 \%$ and $12.5 \%$ ) (Table 2).

\subsubsection{Laelaps differens Fonseca 1936 and}

Laelaps manguinhosi Fonseca 1936

The genus Laelaps Koch 1836 is a large and diverse group of mites of cosmopolitan distribution and generally associated with myomorph rodents, particularly the families Muridae and Cricetidae (Radovsky, 1985; Tipton, 1960). Laelaps manguinhosi frequently infests semiaquatic rodents, like Nectomys and Holochilus (Furman, 1972). Furman
(1972) described two subspecies for L. manguinhosi, indicating that this author was aware that variations could occur in this species.

The genus Nectomys has a wide geographical distribution in South America, from Guianas to Paraguay and northeastern Argentina (Musser and Carleton, 1993; Eisenberg and Redford, 1999). Genetic and morphologic studies of the Brazilian populations of this rodent demonstrate that there are two nominal species: Nectomys squamipes and $N$. rattus (Bonvicino et al., 2008). Twenty-one mites were measured (10 from the Restinga of Jurubatiba and 4 from Praia de Neves associated with $N$. squamipes, and 7 from Distrito Federal associated with N. rattus) (Table 1). For Laelaps manguinhosi specimens collected from $N$. squamipes in RJ and ES clustered together, while the Distrito Federal specimens from $N$. rattus showed a strong tendency to be separate on the third axis (Figure 3).
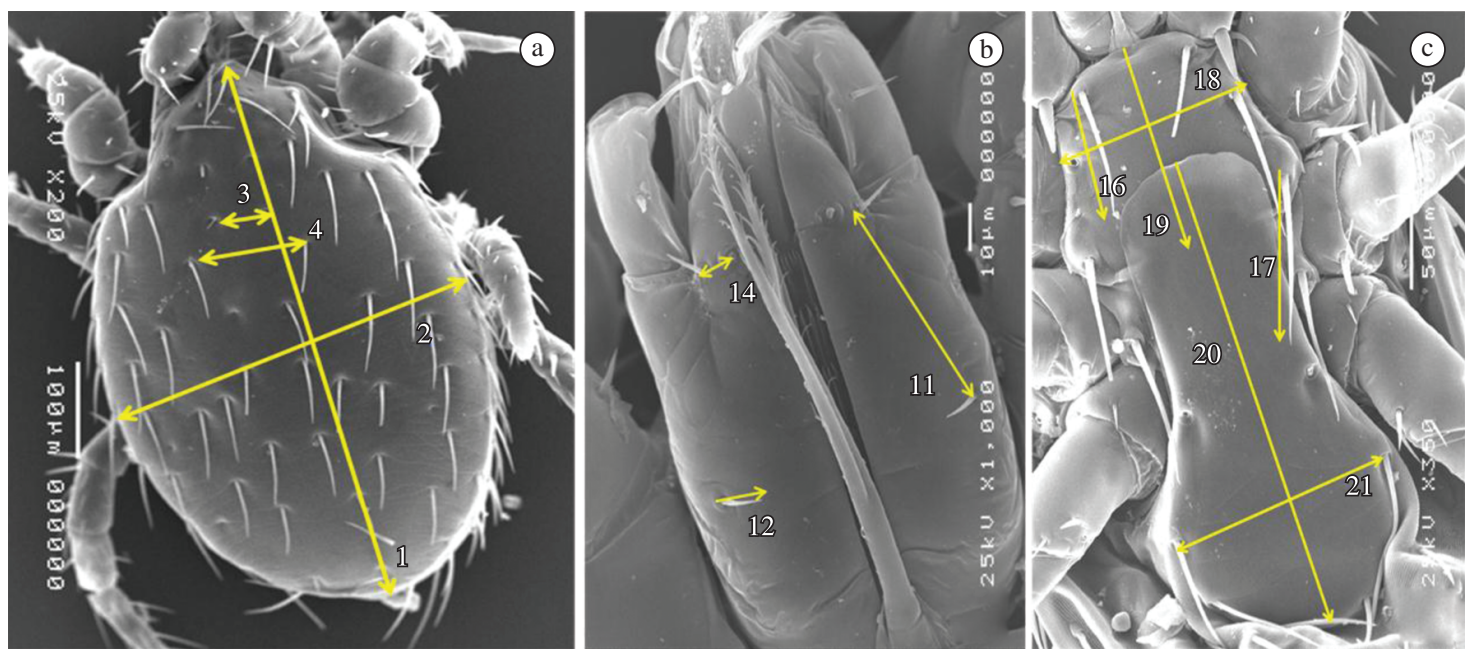

Figure 1. Examples of measurements taken across the whole body of each mite individual. Numbers of measurements corresponds to those in the text. (a) 1- Dorsal shield length (DSL), 2- dorsal shield width at midlevel (DSW), 3- distance between j5 setae (j5-j5), 4- distance between z5 setae (z5-z5). (b) 11- distance between subcapitular setae (CAP-CAP), 12- length of subcapitular setae (CAPL), 14- distance between subcapitular and inner hypostomal setae (CAP-INN), (c) 16-length of anterior sternal setae (S1L), 17- Length of posterior sternal setae (S3L), 18- width of sternal shield at level at second sternal setae (SSW), 19- length of sternal shield (SSL), 20- length of epigynial shield (ESL), 21- distance between epigynial setae (E5-E5).

Table 1. Mite species measured on each host species of the different locations.

\begin{tabular}{lllc}
\hline \multicolumn{1}{c}{ Mite species } & \multicolumn{1}{c}{ Host species } & \multicolumn{1}{c}{ Location } & Number of mites \\
\hline \multirow{2}{*}{ Gigantolaelaps vitzthumi } & Cerradomys vivoi & Chapada Diamantina, BA & 09 \\
& Cerradomys goytaca & Restinga de Jurubatiba, RJ & 04 \\
& Cerradomys scotti & Fazenda Água Limpa, DF & 07 \\
\multirow{2}{*}{ Laelaps differens } & Cerradomys goytaca & Restinga de Jurubatiba, RJ & 14 \\
& Cerradomys goytaca & Praia das Neves, ES & 10 \\
& Cerradomys scotti & Fazenda Água Limpa, DF & 06 \\
Laelaps manguinhosi $i$ & Nectomys squamipes & Restinga de Jurubatiba, RJ & 10 \\
& Nectomys squamipes & Praia das Neves, ES & 04 \\
& Nectomys rattus & Fazenda Água Limpa, DF & 07 \\
\hline
\end{tabular}


Eigenvalues of the three first axes were $11.54 ; 5.53$ and 3.6 and the total variation explained was $64.6 \%(36.1 \%$, $27.0 \%$ and $11.2 \%$ ) (Table 2).

Laelaps differens is a closely related species of L. manguinhosi and its occurrence on the species of the former "Cerradomys subflavus" group has been recorded in several geographic localities (Gettinger, 1992a). Thirty individuals of this mite species were measured, including 14 from Restinga de Jurubatiba, 10 from Praia de Neves, on C. goytaca and 6 from Distrito Federal, associated with $C$. scotti (Table 1). Laelaps differens specimens from different areas formed three distinct groups, with the restinga localities (Jurubatiba and Neves) forming closer groups (Figure 4). However, the mites are distinctly grouped, implying that $C$. goytaca populations from restingas in Espírito Santo and Rio de Janeiro may be more isolated than is presently known. Eigenvalues of the first three axes were $11.29,4.23$ and 3.27 , respectively. The total variation

Table 2. Characters measured on the body of each laelapine mite of Laelaps differens, Gigantolaelaps vitzthumi and Laelaps manguinhosi from the four study areas and weight of each measure in the three first axes of the Main Components.

\begin{tabular}{|c|c|c|c|c|c|c|c|c|c|}
\hline \multirow{2}{*}{$\begin{array}{c}\text { Morphometric } \\
\text { Character }\end{array}$} & \multicolumn{3}{|c|}{ Laelaps differens } & \multicolumn{3}{|c|}{ Gigantolaelaps vitzthumi } & \multicolumn{3}{|c|}{ Laelaps manguinhosi } \\
\hline & 1 & 2 & 3 & 1 & 2 & 3 & 1 & 2 & 3 \\
\hline LDS & 0.65 & -0.32 & -0.49 & 0.66 & 0.66 & -0.11 & 0.64 & -0.26 & -0.44 \\
\hline WDS & 0.72 & 0.10 & -0.39 & 0.79 & 0.35 & -0.24 & 0.89 & 0.08 & -0.34 \\
\hline j5_j5 & 0.72 & 0.10 & -0.39 & -0.18 & 0.72 & 0.38 & 0.47 & -0.56 & 0.31 \\
\hline z5_z5 & 0.45 & 0.16 & -0.26 & 0.76 & 0.28 & 0.17 & 0.03 & -0.14 & 0.39 \\
\hline j5L & 0.37 & -0.81 & -0.14 & 0.26 & 0.69 & 0.07 & -0.06 & 0.82 & 0.09 \\
\hline $\mathrm{z} 5 \mathrm{~L}$ & 0.28 & -0.68 & -0.09 & 0.22 & 0.67 & -0.15 & 0.09 & 0.43 & -0.19 \\
\hline J5_J5 & -0.01 & -0.15 & -0.54 & 0.13 & 0.89 & -0.02 & 0.66 & 0.13 & 0.08 \\
\hline Z5_Z5 & 0.20 & -0.44 & -0.17 & -0.01 & 0.41 & 0.18 & 0.71 & 0.07 & -0.42 \\
\hline $\mathrm{J} 5 \mathrm{~L}$ & 0.70 & -0.37 & 0.18 & -0.26 & 0.68 & 0.37 & 0.11 & 0.86 & 0.09 \\
\hline Z5L & 0.56 & 0.59 & 0.13 & 0.63 & -0.43 & 0.04 & 0.63 & 0.56 & 0.23 \\
\hline CAP_CAP & 0.39 & -0.05 & -0.23 & -0.09 & -0.13 & 0.54 & 0.55 & -0.29 & -0.12 \\
\hline CAPL & 0.02 & -0.33 & 0.42 & 0.31 & 0.11 & -0.62 & -0.67 & 0.60 & 0.21 \\
\hline INNL & -0.01 & 0.12 & 0.54 & 0.09 & 0.15 & -0.67 & - & - & - \\
\hline CAP_INN & 0.69 & 0.01 & 0.30 & 0.57 & -0.53 & 0.21 & 0.04 & -0.29 & -0.63 \\
\hline SSL & 0.56 & -0.30 & 0.06 & 0.88 & 0.07 & 0.35 & 0.80 & -0.21 & -0.00 \\
\hline SSW & 0.70 & -0.37 & -0.11 & 0.85 & 0.14 & 0.31 & 0.79 & 0.01 & 0.14 \\
\hline S1_S1 & -0.47 & 0.24 & 0.24 & 0.51 & -0.57 & -0.23 & 0.81 & -0.32 & 0.31 \\
\hline S3_S3 & 0.31 & 0.43 & -0.53 & 0.86 & -0.24 & 0.20 & 0.84 & -0.15 & 0.28 \\
\hline S1L & 0.63 & -0.06 & 0.53 & 0.21 & 0.79 & 0.12 & 0.61 & -0.19 & -0.11 \\
\hline S3L & 0.75 & -0.17 & 0.24 & 0.45 & -0.17 & 0.75 & 0.84 & -0.00 & -0.06 \\
\hline ESL & 0.54 & 0.48 & -0.42 & 0.87 & -0.23 & 0.07 & 0.83 & 0.01 & -0.08 \\
\hline E5_E5 & 0.68 & 0.23 & -0.09 & 0.72 & 0.17 & -0.55 & 0.65 & 0.37 & 0.25 \\
\hline ESW & 0.70 & 0.37 & 0.07 & 0.41 & 0.63 & -0.15 & 0.88 & 0.17 & 0.05 \\
\hline S4L & 0.47 & 0.10 & 0.33 & 0.81 & 0.33 & 0.23 & 0.59 & 0.46 & -0.46 \\
\hline E5L & 0.61 & 0.14 & -0.05 & 0.56 & 0.10 & 0.01 & 0.55 & 0.46 & -0.52 \\
\hline PARAL & 0.64 & -0.28 & 0.20 & 0.88 & -0.02 & 0.11 & 0.13 & 0.59 & 0.14 \\
\hline POSTL & 0.78 & 0.16 & 0.04 & 0.75 & -0.20 & 0.10 & - & - & - \\
\hline POST_EDGE & 0.55 & -0.39 & -0.26 & 0.09 & 0.45 & 0.08 & -0.07 & 0.89 & -0.16 \\
\hline PARA_PARA & 0.26 & -0.22 & 0.00 & 0.07 & -0.50 & 0.51 & 0.14 & 0.27 & -0.31 \\
\hline ASW & 0.71 & -0.13 & -0.35 & -0.07 & -0.09 & 0.14 & 0.70 & 0.45 & -0.15 \\
\hline PROXCOX & 0.69 & 0.32 & 0.26 & 0.60 & -0.21 & 0.47 & 0.36 & 0.10 & 0.78 \\
\hline DISTCOX & 0.57 & -0.02 & 0.28 & 0.72 & -0.47 & -0.06 & 0.09 & 0.55 & 0.72 \\
\hline POSTCOX2 & 0.61 & 0.26 & 0.50 & 0.61 & 0.48 & 0.02 & 0.70 & -0.31 & 0.33 \\
\hline POSTCOX3 & 0.80 & 0.27 & 0.01 & 0.93 & -0.15 & -0.05 & 0.72 & -0.18 & 0.35 \\
\hline POSTCOX4 & 0.38 & -0.22 & 0.30 & 0.40 & -0.38 & 0.09 & - & - & - \\
\hline DFEM1L & 0.77 & 0.02 & -0.05 & -0.48 & 0.32 & 0.74 & - & - & - \\
\hline DGEN1L & 0.24 & 0.56 & -0.20 & -0.53 & 0.09 & 0.78 & - & - & - \\
\hline
\end{tabular}


explained by the first three axes was $50.7 \%(30.5 \%, 11.4 \%$ and $8.8 \%$, respectively). The restinga localities separated regarding the first axis, while those from Distrito Federal separated mostly by second axis (Table 2).

\section{Discussion}

The analysis of the morphometric characteristics of $L$. differens indicates that mite populations in the Distrito Federal are different from those in restingas of the Atlantic coast of Brazil. These variations may be related to environmental differences among areas, resulting in different selective pressures on populations. Both restinga populations also showed such separation, but on a smaller scale. The restinga areas, in consequence of the high degradation level of this environment, have been fragmented and isolated (Rocha et al., 2003). The lack of contact between host and, consequently, of the mites populations, may have led to a differentiation among these populations. The importance in geographic factors is poorly understood, and often difficult to evaluate because of the lack of knowledge of the species boundaries among the host mammals (Furman, 1972; Gettinger and Owen, 2000).

The population of Gigantolaelaps vitzthumi from Chapada Diamantina formed a distinct group. This population is associated with C. vivoi, and karyotypically distinct from specific populations associated with $C$. scotti from the Distrito Federal and C. goytaca from Restinga de Jurubatiba. This indicates that the mite physical characteristics are strongly dependent of the particular host species with which it is associated. This result illustrates the potential of this study as a tool in elucidating taxonomic relationships of the hosts. Lizaso (1968) described a new species of the genus Gigantolaelaps (G. bahiensis) associated with "O. subflavus" in Feira de Santana, BA. Only one individual mite of the new species was collected and, typical females of G. vitzthumi were found on the same host individual. Furman (1971, 1972) pointed out that morphologic variations are commonly observed in the genus Gigantolaelaps, especially related to body size, and could be associated with differences in the age or food quantity; Furman placed Lizaso's species in synonymy with G. vitzthumi. Our studies indicate that further morphometric analysis and karyotypes of both, mammals and mites, may elucidate whether this mite represents a species distinct from G. vitzthumi and if the host is the recently described species Cerradomys vivoi. It is possible that when carefully examined and measured, Lizaso's G. bahiensis is a distinct species infesting the different host species, C. vivoi.

The morphometric variations between populations of G. vitzthumi from Restinga de Jurubatiba and from Distrito Federal are not clear in contrast with that observed for L. differens. However, the characters used by Gettinger (1992a) as basic for the morphometric studies of laelapine mites are better applied with Laelaps the smaller species. Gigantolaelaps species have very long setae, which are broken easily during the processing for slide mounting. For this reason, a new set of morphological characters may be necessary with these large mites, to detect subtle variations in morphology among closely related hosts.

In Paraguay, Gettinger et al. (2011) found L. manguinhosi associated with five species of rodents in palustrine habitats, including Nectomys, Holochilus, Pseudoryzomys, and Sooretamys. Morphometric studies support the view that this mite was not a single monomorphic species capable of infesting a wide range of host species that share habitats, but is a complex of morphologically similar mite species, each infesting a distinct host species. Our studies in Brazil further verify these relationships, and show that morphometric variation can be measured between species of congeneric Nectomys.

The results obtained at present study indicate that laelapine mite populations can vary among geographic areas and, especially, among phylogenetically related host species. Clearly, the study of these mites at the population level is fundamental to help solving problems in evolutionary biology, especially related to the specificity relations with their hosts (Gettinger, 1992a). The morphometric analysis of laelapines associated with different species of Cerradomys can assist in the differentiation of both the host and mite species, and in the delimitation of their geographical distributions.

Acknowledgements - We would like to thank Dr. N. SerraFreire, Dr. G. Gazêta and Dr. Rui Cerqueira for their support. We thank the Núcleo em Ecologia e Desenvolvimento Sócioambiental de Macaé (NUPEM) of the Universidade Federal do Rio de Janeiro for the logistic support. We thank T.T.L.Ribeiro, Dr. M.A.R. Mello, R. Mangolin, Dr. D.S.L. Raíces and A.G. Alves for their help in the field work. Dr. Lena Geise kindly karyotyped and identified the rodent species of Jurubatiba and Praia das Neves. This study was supported by Conselho Nacional de Desenvolvimento Científico e Tecnológico/Pesquisas Ecológicas de Longa Duração (CNPq/PELD) site 5. FMH

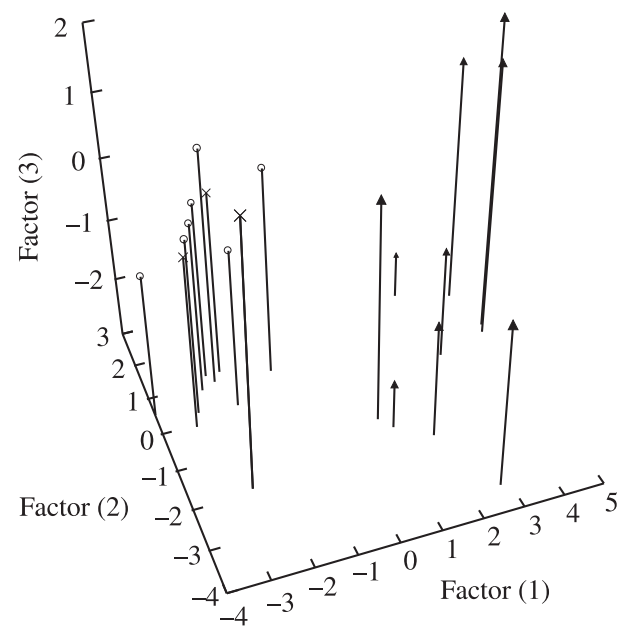

Figure 2. Morphometric variations in three populations of Gigantolelaeps vitzthumi from different localities and host species of Cerradomys: Chapada Diamantina, BA on C. vivoi (triangles); Distrito Federal, DF on C. scotti (circles) and Restinga de Jurubatiba, Macaé, RJ on C. goytaca (crosses). 


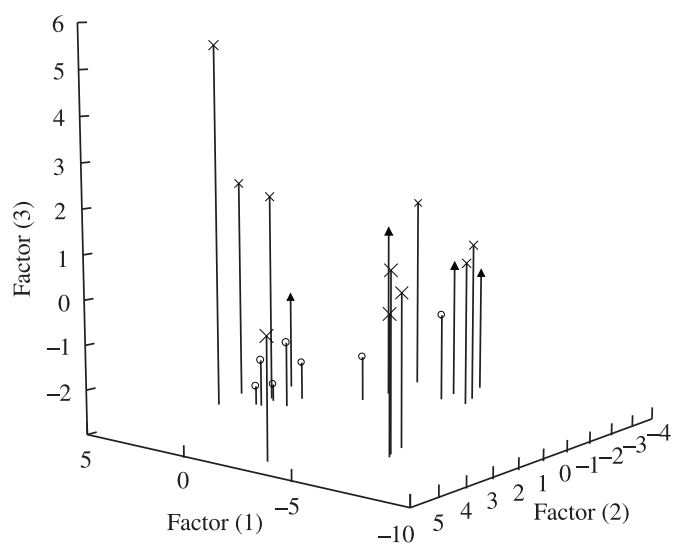

Figure 3. Morphometric variations in three populations of Laelaps manguinhosi from different localities and hosts: Distrito Federal, DF (circles) on N. rattus; Restinga de Jurubatiba, Macaé, RJ (crosses) and Praia das Neves, ES (triangles) on $N$. squamipes.

thanks the CNPq doctoral fellowship and HGB the researcher fellowships from CNPq (Process No. 309527/2006-6), FAPERJ (Process $N^{\circ}$. E-26/102.799/2008) and Prociência/UERJ. Lastly, we thank IBAMA for the collecting permit $\left(\mathrm{N}^{\circ}\right.$. 059/2002). This study is part of a thesis submitted by F. Martins-Hatano to the Departamento de Ecologia of the Universidade do Estado do Rio de Janeiro in partial fulfillment of the requirements for a $\mathrm{PhD}$ in Biology.

\section{References}

ALBRECHT, GH., 1979. The study of biological versus statistical variation in multivariate morphometrics: the descriptive use of multiple regression analysis. Systematic Zoology, vol. 28, p. 338-344. http://dx.doi.org/10.2307/2412586

ANDRADES-MIRANDA, J., OLIVEIRA, LFB., ZANCHIN, NIT. and MATTEVI, MS., 2001. Chromosomal description of the rodent genera Oecomys and Nectomys from Brazil. Acta Theriologica, vol. 46, p. 269-278. http://dx.doi.org/10.1007/BF03192433

ARAÚJO, DSD., 1992. Vegetation types of sandy coastal plains of tropical Brazil: a first approximation. In SEELIGER, U. (Ed.). Coastal Plant Communities of Latin America. San Diego: Academic Press. p. 337-347.

BARROS, DM., LINARDI, PM. and BOTELHO, JR., 1993. Ectoparasites of some wild rodents from Paraná State, Brazil. Journal of Medical Entomology, vol. 30, p. 1068-1970. PMid:8271250.

BEGON, M., HARPER, JL. and TOWNSEND, CR., 1996. Ecology. 3rd ed. Oxford: Blackwell Scientific Publications. 740 p.

BERGALlO, HG., MARTINS-HATANO, F., RAÍCES, DS., RIBEIRO, TTL., ALVES, AG., LUZ, JL., MANGOLIN, R. and MELLO, MAR., 2004. Os mamíferos da Restinga de Jurubatiba. In ESTEVES, FA., SCARANO, FR. and ROCHA, CFD. (Eds.). Pesquisas de Longa Duração na Restinga de Jurubatiba: ecologia, história natural e conservação. São Carlos: RiMa Editora. p. 215-230.

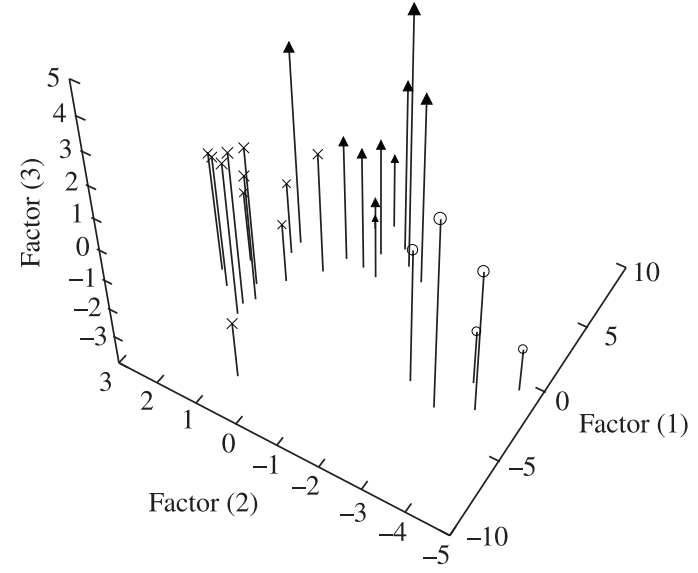

Figure 4. Morphometric variations in three populations of Laelaps differens from different species of the genera Cerradomys: Distrito Federal, DF (circle) associated with C. scotti, Restinga de Jurubatiba, Macaé, RJ (crosses) and Praia das Neves, ES (triangles) associated with C. goytaca.

BITTENCOURT, EB. and ROCHA, CFD., 2002. Spatial use of rodents (Rodentia: Mammalia) host body surface by ectoparasites. Brazilian Journal of Biology, vol. 62, no. 3, p. 419-425.

-, 2003. Host-ectoparasite specificity in a small mammal community in an areas of Atlantic Rain Forest (Ilha Grande, State of Rio de Janeiro), Southeastern Brazil. Memórias do Instituto Oswaldo Cruz, vol. 98, no. 6, p. 793-798. http://dx.doi.org/10.1590/S007402762003000600015

BONVICINO, R., OLIVEIRA, JA. and D'ANDREA, PS., 2008. Guia dos roedores do Brasil: com chaves para gêneros baseadas em caracteres externos. Rio de Janeiro: Centro Pan-Americano de Febre Aftosa - OPAS/OMS.

BOSSI, DEP., LINHARES, AX. and BERGALLO, HG., 2002. Parasitic Arthropods of Some Wild Rodents from Juréia-Itatins Ecological Station, State of São Paulo, Brazil. Memórias do Instituto Oswaldo Cruz, vol. 97, no. 7, p. 959-963. PMid:12471421.

BOTELHO, JR. and WILLIAMS, P., 1980. Sobre alguns ectoparasitas de roedores silvestres do município de Caratinga, Minas Gerais, Brasil. II. Acarofauna. Memórias do Instituto Oswaldo Cruz, vol. 75, p. 47-51. http://dx.doi.org/10.1590/S0074-02761980000200005

BOTELHO, JR., LINARDI, PM. and DE MARIA, M., 2002. Alguns gêneros e subgêneros de Laelapidae (Acari: Mesostigmata) associados com roedores e revalidados através de taxonomia numérica. Lundiana, vol. 3, no. 1, 51-56.

EISENBERG, JF. and REDFORD, KH., 1999. Mammals of the Neotropics. Chicago: University of Chicago Press.

FOOTTIT, RG. and MACKAUER, M., 1990. Morphometric variation within and between populations of the pine aphid, Cinara cinara (Wilson) (Homoptera: Aphidoidea: Lachnidae), in western North America. Canadian Journal of Zoology, vol. 68, p. 1410-1419. http://dx.doi.org/10.1139/z90-210

FURMAN, DP., 1971. New species of Gigantolaelaps (Acarina: Laelapidae) from Venezuela. Journal of Medical Entomology, vol. 8, no. 6, p. 707-712. PMid:5153592. 
-, 1972. Laelapid mites (Laelapidae: Laelapinae) of Venezuela. Brigham Young University Science Bulletin (Biology Serie), vol. 27, 1-58.

GETTINGER, D., 1987. Host associations of Gigantolaelaps (Acari: Laelapidae) in the Cerrado Province of Brazil Central. Journal of Medical Entomology, vol. 24, p. 559-565. PMid:3669028.

-, 1992a. Host specificty of Laelaps (Acari: Laelapidae) in Central Brasil. Journal of Medical Entomology, vol. 29, p. 827-833. PMid:1404262.

-, 1992b. Three new species of Laelaps (Acari: Laelapidae) associated with small mammals in Central Brazil. Journal of Medical Entomology, vol. 29, p. 66-70. PMid:1552531.

-, 1997. Androlaelaps cuicensis (Acari: Laelapidae), a new species associated with Monodelphis rubida (Thomas, 1899) in the gallery forests of central Brazil. Revista Brasileira de Biologia = Brazilian Journal of Biology, vol. 57, p. 345-348.

GETTINGER, D. and BERGALLO, HG., 2003. A new species os laelapinae mite (Acari: Parasitiformes: Laelapidae) associated with Proechimys dimidiatus in the Atlantic forests of Brazil. Journal of Parasitology, vol. 89, no. 4, p. 705-708.

GETTINGER, D. and OWEN, RD., 2000. Androlaelaps rotundus Fonseca (Acari: Laelapidae) associated with Akodontine rodents in Paraguay: a morhometric examination of a pleioxenous ectoparasite. Revista Brasileira de Biologia = Brazilian Journal of Biology, vol. 60, no. 3, p. 425-434. PMid:14533678. http:// dx.doi.org/10.1645/GE-3118

GETTINGER, D., DICK, CW. and OWEN, RD., 2011. Host associations between laelapine mites (Mesostigmata: Laelapidae) and palustrine rodents in Paraguay: a study of host specificity and cryptic species. Systematics and Applied Acarology, vol. 16, p. $145-159$

GUITTON, N., ARAUJO-FILHO, NA. and SHERLOCK, IA., 1986. Ectoparasitas de roedores e marsupiais no ambiente silvestre de Ilha Grande, Estado do Rio de Janeiro, Brasil. Memórias do Instituto Oswaldo Cruz, vol. 81, p. 233-234. http://dx.doi.org/10.1590/ S0074-02761986000200014

LANGGUTH, A. and BONVINCINO, CR., 2002. The Oryzomy subflavus species group, with descriptions of two new species (Rodentia, Muridae, Sigmodontinae). Arquivo Museo Nacional do Rio de Janeiro, vol. 60, no. 4, p. 285-294.

LEGENDRE, P. and LEGENDRE, L., 1988. Numerical Ecology. Amsterdam: Elsevier Science B.V.

LINARDI, PM., BOTELHO, JR., NEVES, DP. and CUNHA, HC., 1984. Sobre alguns ectoparasitos de roedores silvestres de Belo Horizonte, MG. Revista Brasileira de Biologia = Brazilian Journal of Biology, vol. 44, p. 215-219.

LINARDI, PM., BOTELHO, JR. and CUNHA, HC., 1985. Ectoparasitos de roedores da região urbana de Belo Horizonte, MG. III. Ïndices pulicilianos, anoplurianos e acarinos em Rattus norvergicus norvergicus. Memórias do Instituto Oswaldo Cruz, vol. 80, p. 277-284. PMid:3837169.

LINARDI, PM., XIMENES, JRA. and PADOVANI, CR., 1991. Notes on ectoparasites of some small mammals from Santa Catarina state, Brazil. Journal of Medical Entomology, vol. 28, p. 183-185. PMid:2033611.
LIZASO, NM., 1968. Contribuição ao conhecimento dos Laelaptidae do Brasil (Acarina). Papéis Avulsos de Zoologia, vol. 21, no. 13, p. $131-135$.

MARTINS-HATANO, F., GETTINGER, D. and BERGALLO, HG., 2000. Androlaelaps marmosops (Acari: Laelapidae), a new species associated with the mouse opossum, Marmosops incanus (Lund, 1840) in the Atlantic Forest of Rio de Janeiro State. Brazilian Journal of Biology, vol. 61, no. 4, p. 685-688.

-, 2002. Ecology and host specificity of Laelapines (Acari: Laelapidae) of small mammals in an Atlantic forest area of Brazil. Journal of Parasitology, vol. 88, no. 1, p. 36-40. Pmid:12053977.

MARTINS-HATANO, F., RIBEIRO, TTL., JUCÁ, N., COSTA, DP., BAPTISTA, M. and BERGALLO, HG., 2001. Post-natal development under laboratory conditions of Nectomys squamipes (Brants, 1827) and Oryzomys gr. subflavus (Wagner, 1842) (Rodentia, Muridae). Revista Brasileira de Zoologia, vol. 3, no. 2, p. 243-252.

MARTINS-HATANO, F., RAÍCES, DSL., GAZETA, GS., SERRA-FREIRE, NM., GETTINGER, D. and BERGALLO, HG., 2011. Community composition of laelapine mites (Acari: Laelapidae) associated with the nests and fur of Cerradomys subflavus (Wagner, 1842). Journal of Natural History, vol. 45, no. 27-28, p. 1679-1688. http://dx.doi.org/10.1080/00222933. 2011.559690

MUSSER, GG. and CARLETON, MD., 1993. Family Muridae. In WILSON, DE. and REEDER, DM. (Eds.). Mammal species of the world: A taxonomic and geographic reference. Washington: Smithsonian Institution Press. p. 501-755.

OLIVEIRA-FILHO, AT. and FONTES, MAL., 2000. Patterns of floristic differentiation among Atlantic forests in southeastern Brazil, and the influence of climate. Biotropica, vol. 32, no. 4b, 793-810. http://dx.doi.org/10.1111/j.1744-7429.2000.tb00619.x

PERCEQUILLO, AR., HINGST-ZAHER, E. and BONVICINO, CR., 2008. Systematic review of genus Cerradomys Weksler, Percequillo and Voss, 2006 (Rodentia: Cricetidae: Sigmodontinae: Oryzomyini), with description of two new species from Eastern Brazil. American Museum Novitates, vol. 3622, p. 1-46. http:// dx.doi.org/10.1206/495.1

PRICE, PW., 1976. General concepts on the evolutionary biology of parasites. Evolution, vol. 31, p. 405-420.

QUERINO, RB. and ZUCCHI, RA., 2002. Intraespecific variation in Trichogramma bruni Nagaraja, 1983 (Hymenoptera: Trichogrammatidae) associated with different hosts. Brazilian Journal of Biology, vol. 62, no. 4A, p. 665-679.

RADOVSKY, FJ., 1985. Evolution of mammalian mesostigmate mites. In KIM, KC. (Ed.). Coevolution of Parasitic Arthropods and Mammals. New York: Wiley. p. 441-504.

RICKLEFS, RE., 1993. A economia da natureza. Rio de Janeiro: Guanabara Koogan.

ROCHA, CFD., BERGALLO, HG., ALVES, MAS. and VAN SLUYS, M., 2003. A biodiversidade nos grandes remanescentes florestais do Estado do Rio de Janeiro e nas restingas da Mata Atlântica. São Carlos: RiMa.

-, 2005. Endemic and threatened tetrapods in the restingas of the biodiversity corridors of Serra do Mar and of the Central da 
Mata Atlântica in Eastern Brazil. Brazilian Journal of Biology, vol. 65 , no. 1, p. 159-168. PMid:16025914.

SUGUIO, K. and TESSLER, MG., 1984. Planícies de cordões litorâneos Quaternários do Brasil: Origem e nomenclatura. In LACERDA, LD., ARAÚJO, DSD., CERQUEIRA, R. and TURCQ, B. (Eds.). Restingas: origem, estrutura e processos. Niterói: Centro Editorial da Universidade Federal Fluminense. p. 32-56.

TAVARES, WC., PESSÔA, LM. and GONÇALVES, PR., 2011. New species of Cerradomys from coastal sandy plains of southeastern Brazil (Cricetidae: Sigmodontinae). Journal of Mammalogy, vol. 92, no. 3, p. 645-658. http://dx.doi.org/10.1644/10-MAMM-096.1
TIPTON, VJ., 1960. The genus Laelaps with a review of the laelaptinae and a new subfamily Alphalaelaptinae (Acarina: Laelaptidae). University of California Publications in Entomology, vol. 16, p. 233-356.

TURCQ, B., COELHO NETO, R. and FROIDEFOND, JM., 1986. Variability of beach ridges on the coast of Maricá (Rio de Janeiro, Brasil). In RABASA, J. (Ed.). Quaternary of South America and Antartic Peninsula. Rotterdam: Balkema.

WEKSLER, M., PERCEQUILLO, AR. and VOSS, RS., 2006. Ten new genera of Oryzomyine rodents (Cricetidae: Sigmodontinae). American Museum Novitates, vol. 3537, p. 1-29. http://dx.doi. org/10.1206/0003-0082(2006)3537[1:TNGOOR]2.0.CO;2 
